\title{
P-8 HYDROCARBON POTENTIAL OF MEDITERRANEAN REGION
}

HILMAR REMPEL

Bundesanstalt für Geowissenschaften und Rohstoffe, Stilleweg 2. 30655 Hannover, Germany

Mediterranean region comprises the littoral states of the Mediterranean Sea. Seen in a global framework, the hydrocarbon reserves and production of these countries are relevant. Their combined share of world production lies between 5 and $6 \%$, of the world reserves at about $4 \%$, resources between 2 and $4 \%$; consumption is higher (see fig. 1 ).

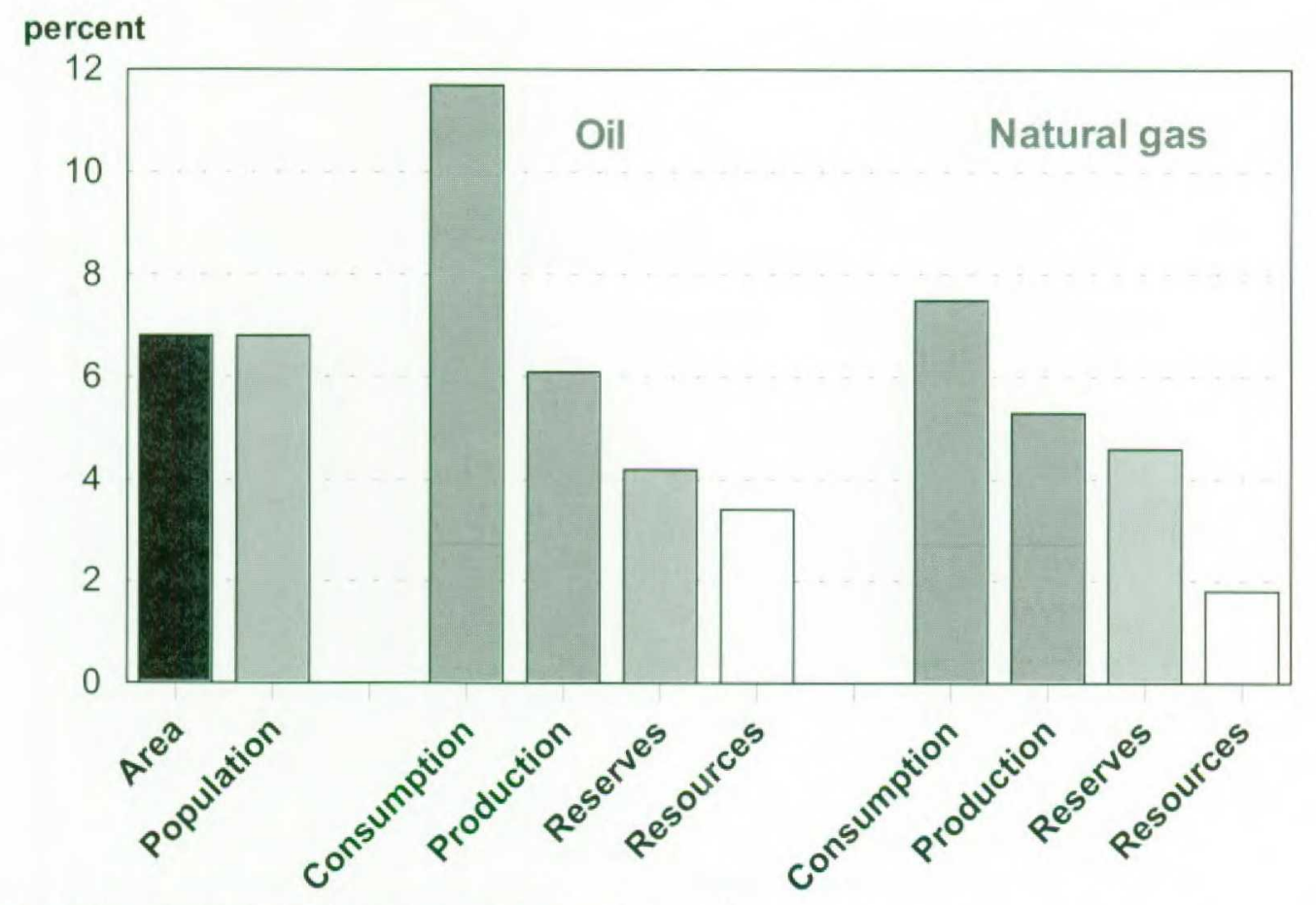

Fig. 1: Mediterranian region - share of world

According to BGR (1998), updated to year-end 1998 the common reserves of crude oil and condensate of Mediterranean countries exceed 6,300 million tons, the natural gas reserves 7,100 billion $\mathrm{m}^{3}$. In 1998 the Mediterranean countries produced 217,4 million tons of crude oil and condensate and 125,7 billion $\mathrm{m}^{3}$ of natural gas. The cumulative production is 6,635 million tons of oil and 2,314 billion $\mathrm{m}^{3}$ of natural gas. The hydrocarbon resources are estimated at 2,580 million tons of crude oil and condensate and 3,940 billion $\mathrm{m}^{3}$ of natural gas.

The distribution according share of area, population, consumption, production, reserves and resources is uneven between European and Africa/Middle East countries (see fig. 2). European countries are in front 
by population and consumption of oil and gas, Africa/Middle East countries are dominating by area, production, reserves and resources of oil and gas.

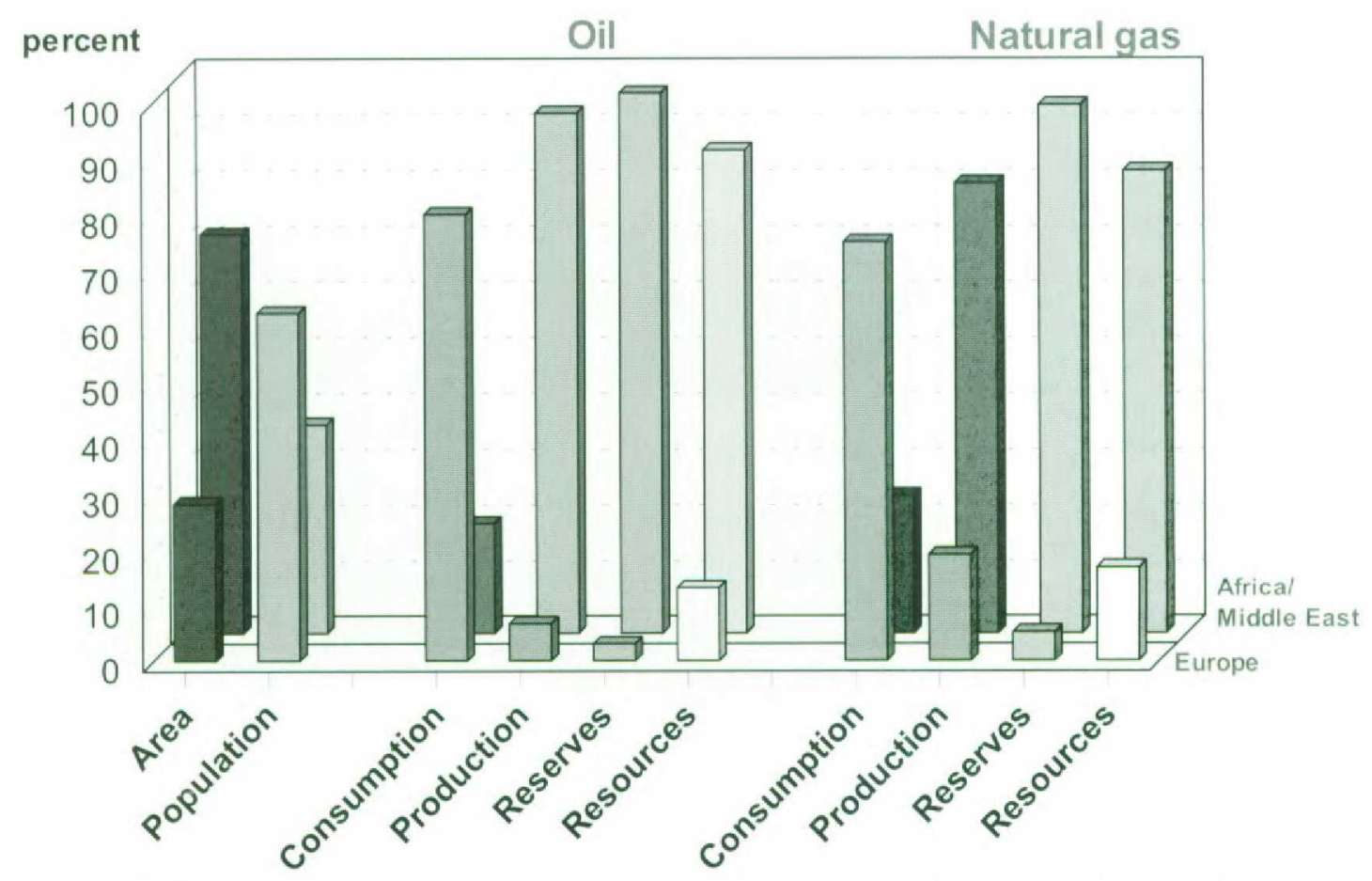

Fig. 2: Mediterranean region - share of European and Africa/Middle East part

Development of oil production in the main Mediterranean countries since 1950 is shown in fig. 3. There are 3 dominating oil producers: Libya, Algeria and Egypt (see also fig. 4). Libya and Algeria are OPECmembers. In 1970 Libya was on rank 6 among the world oil producers.

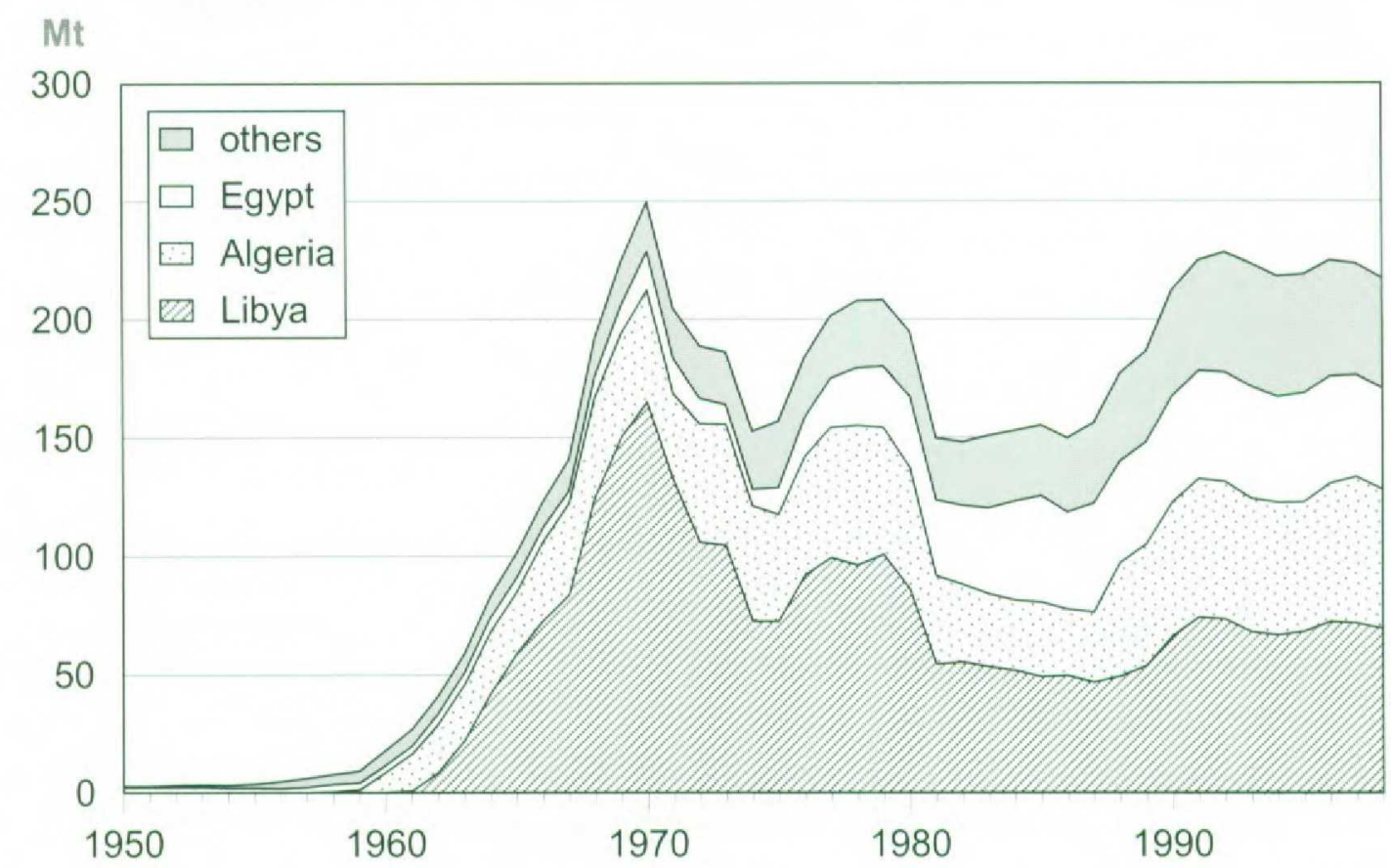

Fig. 3: Development of oil production in the main Mediterranean countries from 1950 1998 ( in million tons) 
Main gas producers of the region are Algeria (74 bn cm in 1998), Italy (19.2 bn cm) and Egypt (14.2 bn $\mathrm{cm}$ ) (see fig. 5). Algeria is ranking on position 6 among the world gas producers.

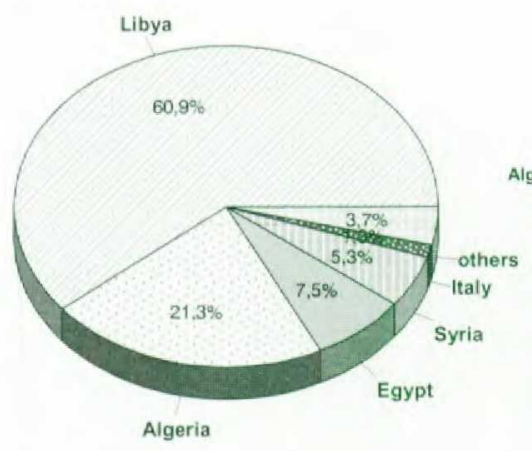

Reserves

$(6,305 \mathrm{mln} \mathrm{t})$

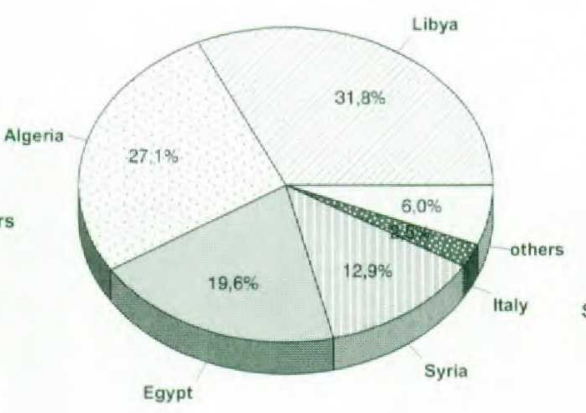

Production

$(214.7 \mathrm{mln} \mathrm{t})$

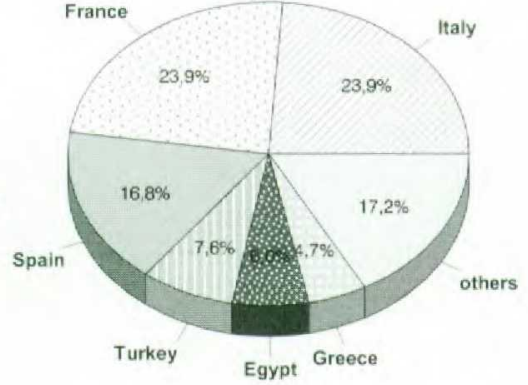

Consumption

$(396.1 \mathrm{mln} \mathrm{t})$

Fig. 4: Distribution of reserves (by year-end 1998), production, and consumption of crude oil and NGL in the main Mediterranean countries in 1998

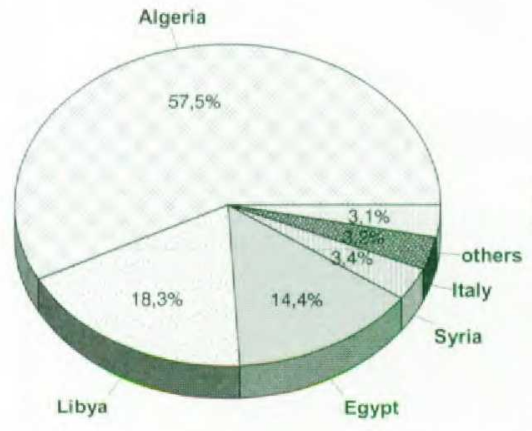

Reserves

$(7,090 \mathrm{bn} \mathrm{cm})$

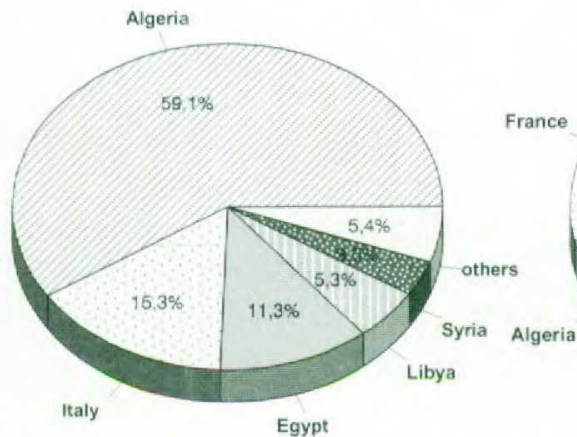

Production

$(125.2 \mathrm{bn} \mathrm{cm})$

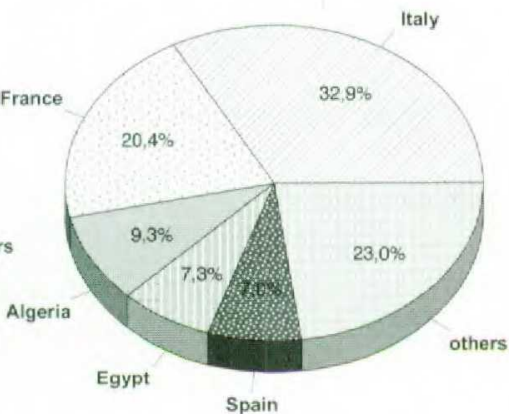

Consumption

$(172.7 \mathrm{bn} \mathrm{cm})$

Fig. 4: Distribution of reserves (by year-end 1998), production, and consumption of natural gas in the main Mediterranean countries in 1998

There are basins of different geodynamic setting (ALZARD 1993, Petroconsultants 1986, , KUHLKE 1994, 1995, PERRODON 1993, VYSOTSKY et al. 1994).. According to VYSOTSKY et al. (1994) the continental basins occur on platforms (Alger-Libyan and Murzuk) and on orogenic belts (Pre-CarpathianBalkanian, Pannonian, North Aegean, Atlas), the transition basins occur on relict margins (AlgerProvencal, Adriatic-Ionian), active continental margins (Crete, Aquitaine, Tunis-Sicilia, Sahara-East Mediterranean), and intraplate rifts (Golf of Suez). The petroleum systems obtain a wide stratigraphic range from Silurian to Oligocene-Miocene.

There are several giant oil and gas fields, especially in Algeria, Libya and Egypt. Exploration in the offshore area is poorly. There are some offshore fields in Egypt, Tunisia, Libya, Italy, Spain, Croatia and Greece.

Most of the countries studied are prospective for hydrocarbons. According to MASTERS et al. (1998) the most promising basins for oil and gas are Alger-Libyan, Pelagian, Golf of Suez, Adriatic and East Mediterranean; for gas also Nile Delta and Central Mediterranean basins are of interest. 
In the European part a good developed pipeline network for oil and gas exists. Sources for oil deliveries into the Mediterranean region are the North Seà, Russia and Middle Eästern countries. The Mediterranean countries are part of the European gas market, connected with fields in the North Sea and in Russia. There are 2 connections between Northern Africa and southern Europe for supply of Algerian gas to Italy (via Tunisia and Sicily) and the Iberian peninsula (via Morocco and Gibraltar). A third line from Libya to Italy is planned.

Unconventional oil is known in Mediterranean region too. According to BGR (1998) the reserves of unconventional oil (heavy oil) are estimated at 720 million tons $(0.5 \%$ of world reserves), which are concentrated in Syria, Egypt, Italy and Albania. The resources are estimated at 4,600 million tons ( $0.5 \%$ of world resources) with domination of heavy oil in Italy and oil shales in Morocco, Egypt and Israel. Unconventional gas reserves are unimportant.

\section{References}

Alzard, N., J. Laherrere and A. Perrodon (1993): Oil and Gas Reserves and Resources of the Mediterranean Countries. Energy Exploration and Exploitation. 11, 5. p. 389-713.

BUNDESANSTALT FÜR GEOWISSENSCHAFTEN UND ROHSTOFFE (BGR) (1998): Reserven, Ressourcen und Verfügbarkeit von Energierohstoffen 1998.- XVII $+400 \mathrm{~S}$., Schweizerbart sche Verlagsbuchhandlung (Nägele und Obermiller), ISBN 3-510-95842-X, Stuttgart.

BPAmoco (1999): BPAmoco Statisatical Review of World Energy, June 1999

KuHLKe, H. (Hrsg.) (1994): Regional Petroleum Geology of the World. Part I: Europe and Asia, Gebrüder Bornträger Berlin

Kuhlke, H. (Hrsg.) (1995): Regional Petroleum Geology of the World. Part II: Africa, Amerika, Australia and Antarctica, Gebrüder Bornträger Berlin

MASTERS, C.D., ROOT, D.H AND R.M. TURNER (1998): World Conventional Crude Oil and Natural Gas: Identified Reserves, Undiscovered Resources and Futures. U. S. Geological Survey Open-File Report 98-468

PERRODON, A. (1993): Overview of African petroleum systems. Oil \& Gas Journal 91, 28. p. 115-118

Petroconsultants (1986): World Sedimentary Basins Petroconsultants Geneve

Petroconsultants (1998): Foreign Scouting Service Petroconsultants Geneve

Vysotsky, V.I., IsAEV, E.N., KleStChov, K.A., MilitenKo, N.V., NAMESTNiKov, Yu.G., Fyodorov, D.L. (Ed.) (1994): Map of World Oil and Gas Potential. Scale 1:15 000 000. Explanatory Note.VNIIzarubezhgeologia, Moscow. 